
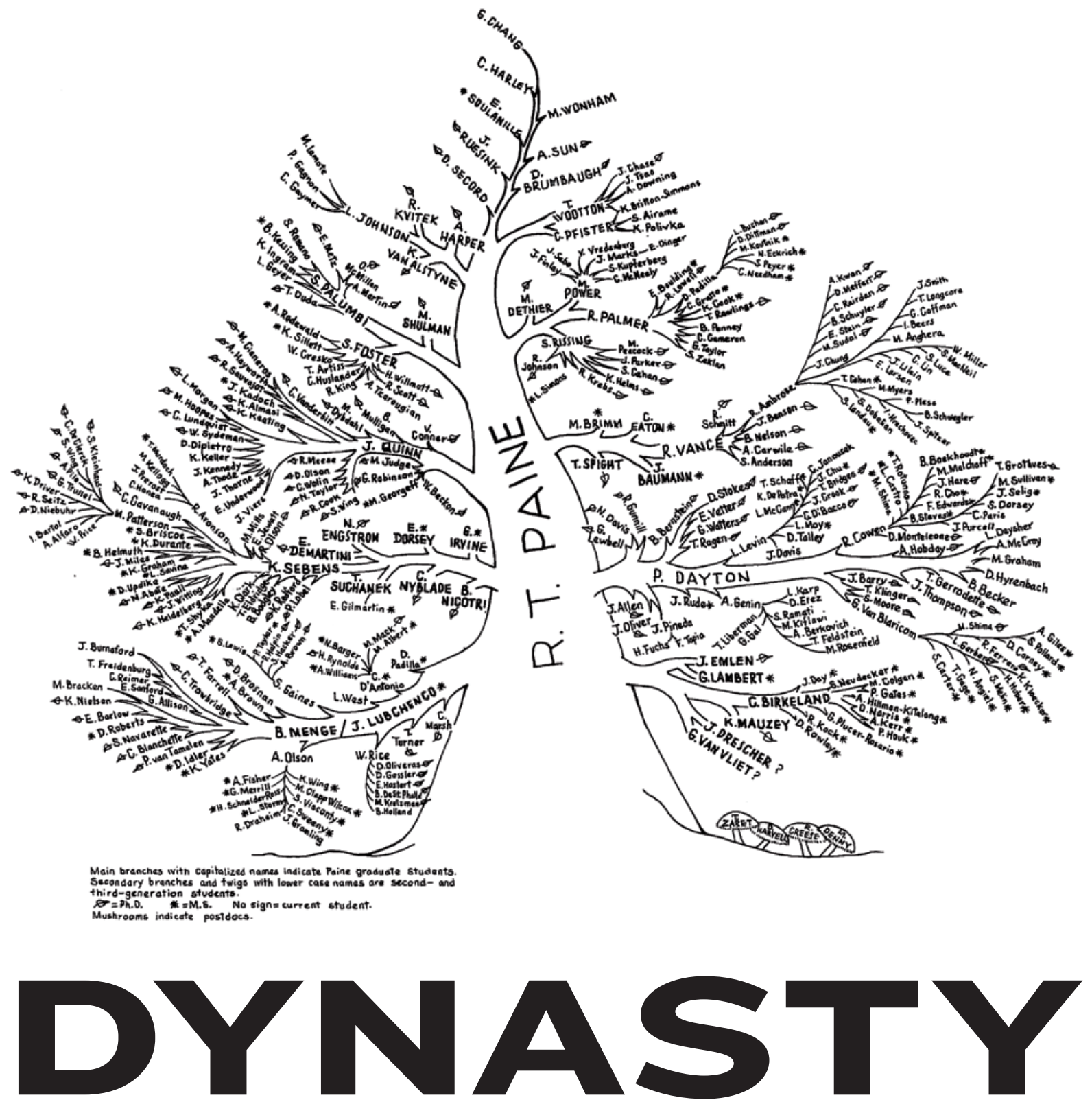

Bob Paine fathered an idea - and an academic family - that changed ecology.

\author{
BY ED YONG
}

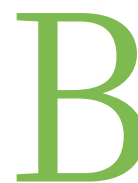

ob Paine is nearly 2 metres tall and has a powerful grip. The ochre sea star, however, has five sucker-lined arms and can span half a metre. So when Paine tried to prise the creatures off the rocks along the Pacific coast, he found that his brute strength simply wasn't enough. In the end, he resorted to a crowbar. Then, once he had levered the animals up, he hurled them out to sea as hard as he could. "You get pretty good at throwing starfish into deeper water," he says.

It was a ritual that began in 1963, on an 8-metre stretch of shore in Makah Bay, Washington. The bay's rocky intertidal zone normally hosts a thriving community of mussels, barnacles, limpets, anemones and algae. But it changed completely after Paine banished the starfish. The barnacles that the sea star (Pisaster ochraceus) usually ate advanced through the predator-free zone, and were later replaced by mussels. These invaders
Bob Paine's academic family tree, drawn by Marian Kohn in 1999. 
crowded out the algae and limpets, which fled for less competitive pastures. Within a year, the total number of species had halved: a diverse tidal wonderland became a black monoculture of mussels ${ }^{1}$.

By re-engineering the coastline in this way ${ }^{1}$, Paine dealt a serious blow to the dominant view in ecology of the time: that ecosystems are stable dramas if they have a diverse cast of species. Instead, he showed that individual species such as Pisaster are prima donnas, whose absence can warp the entire production into something blander and unrecognizable. He described these crucial creatures, whose influence far exceeds their abundance, as keystone species, after the central stone that prevents an arch from crumbling. Their loss can initiate what Paine would later call trophic cascades - the rise and fall of connected species throughout the food web. The terms stuck, and 'keystone' would go on to be applied to species from sea otters to wolves, grey whales and spotted bass.

Today, ecology students take these concepts for granted - but they shook the field when Paine first articulated them in the 1960s. "He's been one of the most influential ecologists in the last half century," says Simon Levin, a mathematical ecologist at Princeton University in New Jersey, and one of Paine's closest friends. The revelation that not all species are equal was as disruptive to ecology as the loss of Pisaster was to Makah Bay. So was Paine's insistence on tinkering with nature - what some have called kick-it-and-see ecology — at a time when most ecologists simply observed it.

But Paine - an organism whose disproportionate influence equals that of any starfish or sea otter - has also changed the ecosystem of scientists. In his five-decade career, he has trained a thriving dynasty of around 40 students and postdocs, many of whom are now leading ecologists themselves and who consider their time with Paine formative. They include Paul Dayton at the Scripps Institution of Oceanography in La Jolla, California, who has shaped understanding of rocky shores, kelp forests and Antarctica's sea floor; Bruce Menge at Oregon State University in Corvallis, who expanded Paine's research to coasts worldwide; Jane Lubchenco, who heads the US National Oceanic and Atmospheric Administration (NOAA) in Washington DC; and Steve Palumbi at Stanford University in California, who used genetics to track the illegal trade of whale and dolphin meat.

"There are other ecologists as famous as Bob, but if you look at their list of students, there aren't nearly as many whom you know by reputation," says Chris Harley at the University of British Columbia in Vancouver, Canada, who was one of Paine's most recent PhD students. Once Paine's students' students are taken into account, his academic family easily stretches into the hundreds. "Everyone is tied to Paine," says Craig McClain, a deep-sea biologist at the National Evolutionary Synthesis Center in Durham, North Carolina, who is three links removed - his postdoctoral adviser was Dayton's student.

\section{FAMILY VALUES}

Science hosts many such dynasties: successions of academic leaders related not by blood, but by mentorship. Each generation inherits attitudes, philosophies and technical skills from the one before. Some, like Paine's, are particularly fertile, sprouting lush branches on the academic tree and driving a field in a new direction. But Paine's dynasty is remarkable not just for its scientific influence, but for its dedicated, tight-knit nature. Thanks to Paine's original — and widely applicable — ideas, his emphasis on independent thought by his protégés and his fun, irreverent nature, almost every member has stayed in science, and specifically in ecology or marine biology.

"It's a surprising list of superstars - great mentors of graduate students, who have published interesting work," says Paine, who retired in 1998 but is still active in the field. These days, Paine can be spotted at ecological meetings by the swarm of academic descendants milling around him. Perhaps in this rich family, there are lessons about why some scientific dynasties flourish and grow, whereas others never bud.
Paine's name is synonymous with coastal life, but his introduction to natural history began on terra firma. As a child in Massachusetts, he went on regular birdwatching walks with a neighbour, who insisted that he record everything he saw. "That was extraordinarily good training," says Paine; it instilled an appreciation for nature and careful observation.

After studies at Harvard University in Cambridge, Massachusetts, and two years' military service, he got his $\mathrm{PhD}$ in zoology from the University of Michigan in Ann Arbor, under the late Fred E. Smith. A qualified ecologist in search of an ecosystem, Paine started his own group at the University of Washington in Seattle in 1962 and embarked on his seminal work in Makah Bay. But despite its abundance of starfish, the bay was plagued with marauding beachcombers, who would tamper with Paine's experiments. He craved isolation.

He found it in 1967, after a salmon-fishing trip in the Pacific Ocean, when on a whim he landed on a small island called Tatoosh, just off Washington's Olympic Peninsula. "I just sat around and gawked," he says. "The place was a wonderland of pattern." He saw hundreds of species jostling for space and dominance. He saw starfish prising open mussels, and predatory sea snails drilling into barnacles. He saw whales and sea lions swimming offshore, while raptors and seabirds hovered overhead. And he saw... no one else. With the island protected by the local Makah tribe, there was no one around to ruin his experiments. "I said: this is where I'm going to work."

\section{ISLAND RETREAT}

Paine repeated his starfish-clearing experiment on Tatoosh, and saw the same events unfold on a bigger scale: the loss of Pisaster triggered a black landslide of mussels that crushed its way down 40 metres of coast. Elsewhere, in a zone dominated by brown algae, Paine systematically added or excluded seven grazing animals by building rings of paint and putty ${ }^{2}$. Two of the species - a sea urchin and a mollusc called a chiton - would annihilate the algae when present in high numbers. The others, all molluscs, had no effect. "It was a colossal effort," says Paine, and the first time that anyone had quantified the influence of so many species in a community. It showed that most are weak interactors, whose absence goes unnoticed. Only a few — including keystone species - are strong interactors that can radically reshape their world. "It was a starting place for untangling the complexity of interactions," says Paine. "If all species were created equal, you wouldn't know where to start."

Paine's views on experimental ecology rapidly percolated through the field, and attracted waves of eager students. "It was a pioneering stage in the field," says Menge. "We felt that we were really the first ones to be doing these sorts of experiments." Tatoosh gave them a place to experiment, and most of Paine's protégés have done tours on its weatherbeaten terrain. They camped in garage-sized buildings, abandoned from the island's days as a coastguard outpost. There was no running water and, until a decade ago, no electricity. "It was a brutal environment, and I was out there suffering with them," says Paine. He kept the atmosphere spartan, splashing out only on heavy-duty clothing and boots - the "Paine lab uniform".

Unlike many principal investigators, who dole out predefined projects to new recruits, Paine encouraged freedom and individuality. "He was hands-off until it was necessary to be hands-on," says Menge. Students walked to disparate corners of the island to explore their own passions. One tagged larval rockfish; another studied barnacle dynamics. In the evenings, the group traded data over campfires. "You'd have a day of working the shoreline, you'd trudge back up to the island, and he invariably asked: What did you learn today?" says Tim Wootton from the University of Chicago, Illinois, who studied under Paine in the 1980s. Paine set a high intellectual bar, and was gruff and challenging. "He's very brusque and abrupt, and he kind of scowls a lot," says Lubchenco. But he also encouraged irreverence and mischief - he once signed the name of his friend, Peter Kareiva, on Christmas cards full of lascivious 
limericks and posted them to the world's top ecologists.

Paine treated his students as peers, supporting their endeavours without directing them. (Smith had treated Paine the same way.) When they published, he kept his name off their papers unless he had had a heavy hands-on role in the research — an ethos that seems unthinkable today. "It hurt him a bit," says Kareiva, now chief scientist for the Nature Conservancy, an environmental organization based in Arlington, Virginia. "His presence in the literature would be ten-fold if he hadn't done that." Harley adds: "If Bob Paine were reborn into the system as a junior professor right now, he would turn out excellent graduate students but I don't know how many grants he'd get.'

Soon, Paine's students were growing up and embarking on careers of their own. Few have spawned as rich a legacy as Jane Lubchenco and Bruce Menge. They met as graduate students in Paine's lab in 1969, married two years later and began a partnership that has generated
Lubchenco and Menge wanted to probe other environmental impacts on coastal ecosystems, and so began a decades-long world tour that took Paine's experimental approaches to Chile, South Africa and New Zealand. Their studies showed ${ }^{4}$, for example, that the intermittent upwelling of nutrient-rich water can intensify competition, predation and other interactions between marine species.

But they also moved - to Paine's disapproval — from his solitary style to large teams. Their grandest venture is the Partnership for Interdisciplinary Studies of Coastal Oceans (PISCO) - a 13-lab collaboration that began in 1999. The participants run regimented studies along a 1,900-kilometre stretch of coastline from Alaska to Mexico, including a census of local marine life and measurements of water conditions. There are some Paine-style manipulations, but PISCO is more about collecting data to reveal how the oceans are changing. When Oregon's beaches started filling with dead crabs and fish in 2002, PISCO's data quickly
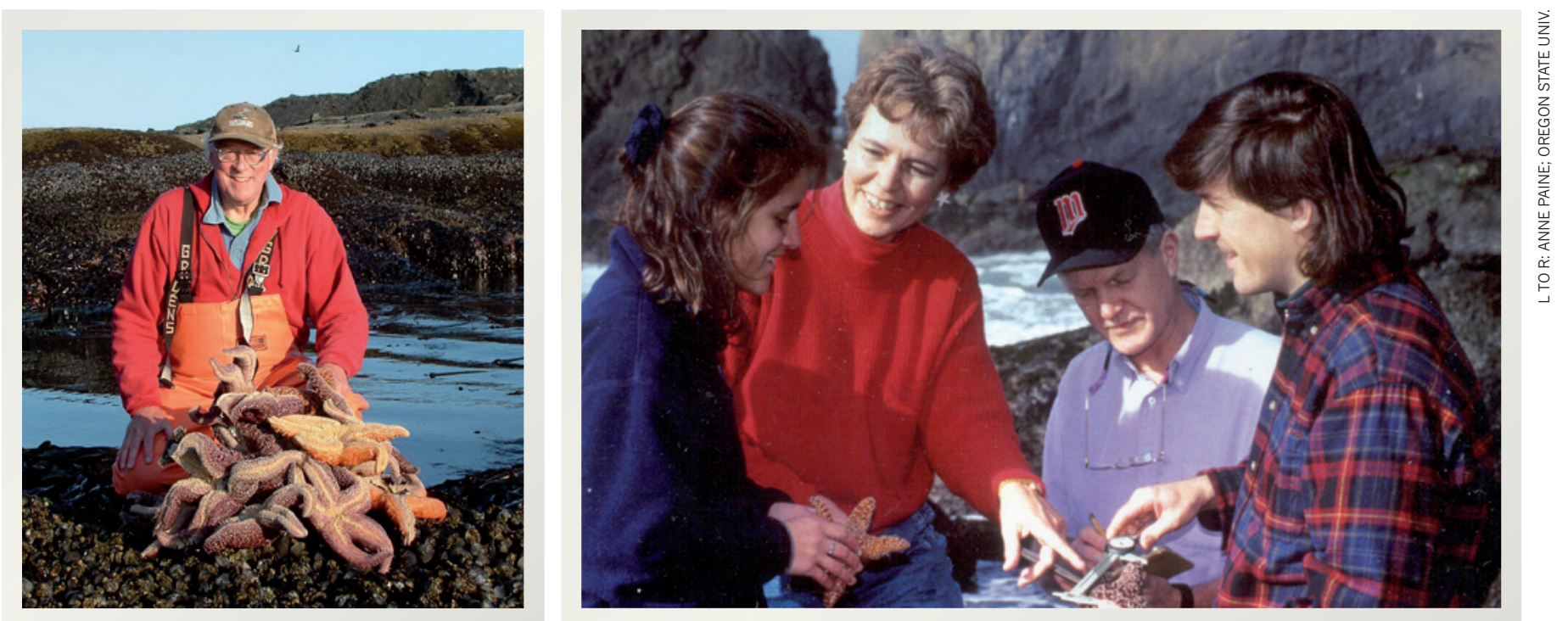

Bob Paine with starfish on Tatoosh island, Washington, in 2011 (left); Jane Lubchenco and Bruce Menge with students Eric Sanford and Tess Freidenburg, 1997.

more than 31 students and 19 postdocs. After the pair left Paine's lab, they took his experimental approach to the US east coast; she focused on plants and herbivores, while he concentrated on predators. By enclosing, excluding and removing species at different points along the New England shore, they showed ${ }^{3}$ that fierce waves can keep predators such as starfish at bay, allowing mussels to dominate. But in sheltered areas, predators kept mussels under control, allowing Irish moss (Chondrus crispus), a type of red alga, to take over. The work revealed how the environment can control interactions between species.

\section{GROWING ECOSYSTEM}

After divvying up the New England food web between them, Lubchenco and Menge also split a tenure-track faculty position when they returned west to Oregon State University in 1976. This move, unprecedented at the time, allowed them to further their careers while spending time with their growing family. (One of their children, Duncan Menge, accompanied the Paine clan on field trips and this year is setting up his own ecology lab at Columbia University in New York - a blood child of the academic family.)

The students of the cheerfully described "Lubmengo lab" benefited from the yin-yang qualities of their mentors. Menge was impulsive and had an open-door policy. Lubchenco was deliberate and required appointments. Today, he is laid-back and wears Hawaiian shirts; she is intense and sharp-suited. "The combination of those two was really powerful," says Steve Gaines from the University of California, Santa Barbara, who was one of their star students. "You got an educational experience that would be hard for any individual to give you."

revealed the cause - an oxygen-deprived dead zone that had been mysteriously growing in the water off the coast (see Nature 466, 812-814; 2010). "The problems we're trying to solve in ecology are way beyond the local scale," says Menge. "My dream is for PISCO-like entities in all the marine ecosystems around the world."

But that is not Paine's dream: big science is an anathema to him. "He was always grousing about how this massively expensive work was really not much more than stamp-collecting," says former student Richard Palmer, now at the University of Alberta in Edmonton. Paine fears that PISCO's approach will yield broad, unclear trends rather than detailed insights. Worse, it risks robbing students of the playful creativity that he tried to instil. "They're so involved with making the same measurements up and down the same kilometres of coast," he laments. "My looseygoosey attitude to Tatoosh was to get brilliant people to do what they want to do." But Lubchenco and Menge argue that ecology's challenges, from global warming to ocean acidification, are outpacing the rhythms of solo experiments. "Bob fought that a lot," says Lubchenco. "People had to rebel against their parent."

Lubchenco's move into policy was similarly rebellious. She served as president of the American Association for the Advancement of Science in 1997 and of the Ecological Society of America between 1992 and

\section{ONATURE.COM} For more about Bob Paine's dynasty, listen to the podcast: go.nature.com/olfjxo 1993. And as administrator of NOAA from 2009, she has influenced the US government's response to the Deepwater Horizon oil spill, and its strategy to manage the oceans sustainably. "The culture we grew up with was very anti being relevant," says Lubchenco, who will leave NOAA at the end of 
February to return to research. "I knew Bob didn't approve and I did it anyhow. It was really painful to rebel."

Any such disapproval has long since vanished, and Paine now speaks of Lubchenco's influence with deep respect. He has reluctantly become a key player in conservation himself, leading panels of scientists who have assessed the decline of the Steller's sea lion (Eumetopias jubatus) and the recovery of Alaskan waters following the 1989 Exxon Valdez oil spill. "My role was simply to oversee the mob," he says. "I was bullied into it."

\section{NEXT GENERATION}

Lubchenco's academic children - Paine's grandchildren - have been steeped in 'relevance' from the start. "We were all surrounded by this environment where it was encouraged to think about steps connecting the science to policy," says Heather Leslie at Brown University in Providence, Rhode Island, a former Lubchenco student. work in drug metabolism and Julius Axelrod, who was awarded a Nobel prize for his work on the release of neurotransmitters - helped to revolutionize human pharmacology and neuroscience. "Their approach was: Don't feel you have to have all your i's dotted and t's crossed. Just go and do it," says Robert Kanigel, a writer who chronicled the dynasty in his book Apprentice to Genius (Macmillan, 1986).

But the Shannon lineage was radically different from Paine's. There was no premium on independence; instead, students served as apprentices to their masters. "In many of the key experiments, the younger person was doing the work of the mentor, and that sometimes led to resentments," says Kanigel. Such relationships can breed envy and mistrust, he says. "People wonder if they'll get the credit they deserve."

Paine proves that the opposite strategy works. "Treat your graduate students as human beings and be accessible to them. That sense of social equality is very important," he says. "All my students were smarter than
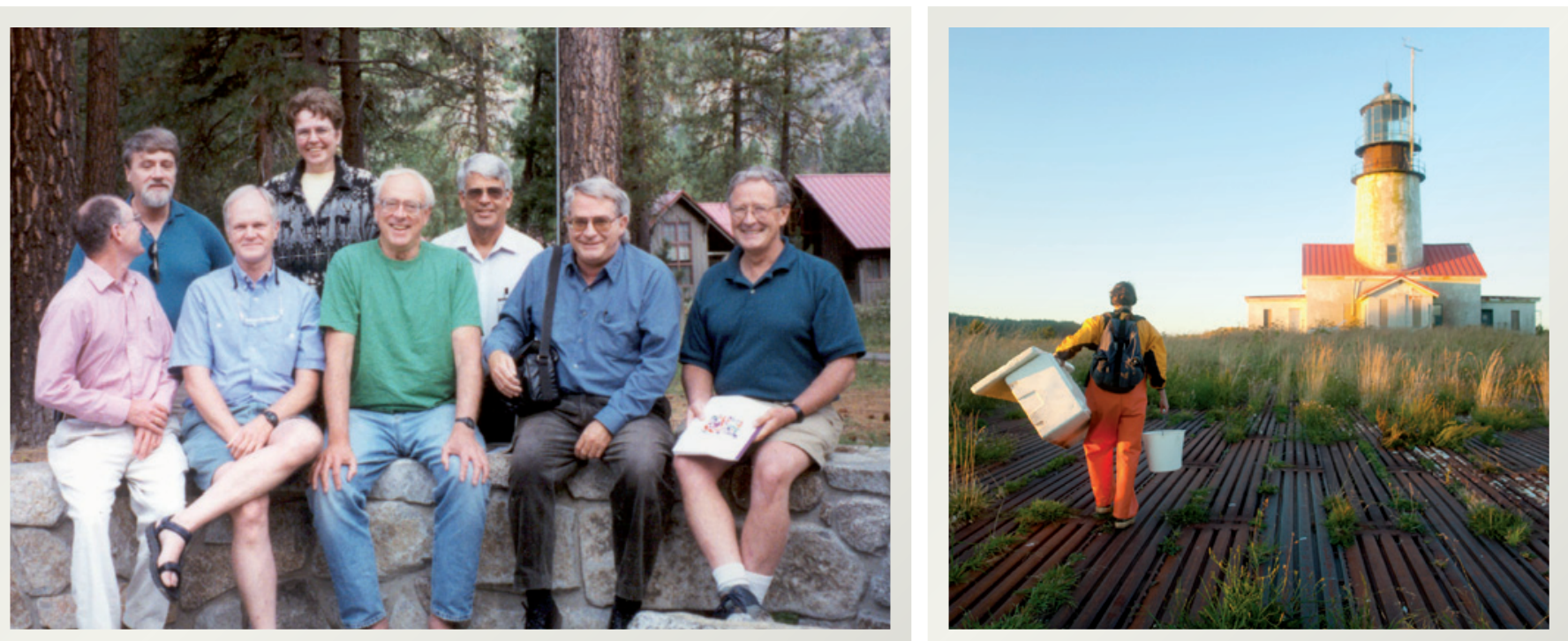

Paine (front row, centre) surrounded by colleagues and protégés at his retirement party in 1999 (left); Paine's former student Cathy Pfister on Tatoosh in 2012.

Gaines epitomizes this approach. The ultimate blend of the Paine and Lubmengo heritage, he is an experimental ecologist who uses basic science to influence policy, is not shy of collaborations and has won a national award for mentoring. "Steve sits right at that sweet spot in many different ways," says Lubchenco. Whereas Paine studies how species interact on individual shores, Gaines looks at connections across entire oceans. He has shown ${ }^{5}$ that the larvae of fish and other marine life sometimes drift for hundreds of kilometres on ocean currents, even if the adults are fixed in place. "When Bob removed the sea star and got an explosion of mussels, those mussels were coming from somewhere else," he says. These planktonic drifters connect disparate parts of the ocean, with huge implications for marine reserves, where fishing is forbidden. Rather than reducing fish catches, Gaines showed ${ }^{6}$ in 2005 that these reserves have the potential to make nearby fisheries more productive as their larvae disperse and replenish the stocks.

Gaines' own students, in the style of the entire family, have branched out into new areas. Kate Smith, who did her $\mathrm{PhD}$ with him and is now at Brown, applied Gaines' ideas on dispersing larvae to understand how infectious diseases disperse. Her ecological interests are the same as those of her academic parents and grandparents - where organisms are, why they are there and how they influence each other - but applied to microbes and continents, rather than invertebrates and tidal pools. "It's all related to connectivity," says Gaines.

There are other ways than Paine's to spawn a dynasty. Take, for example, the chain of biological luminaries that emerged in the 1940s, beginning with physiologist James Shannon at the US National Institutes of Health. His descendants - including Steve Brodie, who did pioneering me but just less knowledgeable." This attitude selected for self-propelled, passionate students who could find their own way. "It helped in getting the experience to implement your own research programme," says Wootton.

Now aged 79, Paine is still conducting research and inspiring students. He joined a crop of them last summer for a week in Patagonia. "He'd be in the intertidal on his hands and knees and asking questions," says Kareiva, who was also on the trip. Paine also makes regular excursions to Tatoosh, where research is now run by Wootton and his wife, Cathy Pfister, who is also at the University of Chicago. Paine's mind is as sharp as ever, but having lost good binocular vision, his steps are less sure. "I hire my very athletic daughter to haul me around the rocks," he says. "It's not sufficient, but I can continue to keep track of my long-term experiments."

In 1995, Paine finally allowed starfish to return to the Tatoosh shore after 25 years of continuous exile. "I thought, I'm not going to live forever, so let's see what happens if I let the starfish back." Their numbers have rebounded, the mussels are losing ground, and the shore is returning to the state it was in before Paine's interference. The same cannot be said for ecology. It will never be the same after Paine.

Ed Yong is a freelance writer and author of the blog Not Exactly Rocket Science, based in London.

1. Paine, R. T. Am. Nat. 100, 65-75 (1966).

2. Paine, R. T. Nature 355, 73-75 (1992)

3. Lubchenco, J. \& Menge, B. A. Ecol. Monogr. 48, 67-94 (1978).

4. Menge, B. A. et al. Ecol. Res. 17, 1-16 (2002)

5. Kinlan, B. P. \& Gaines, S. D. Ecology 84, 2007-2020 (2003).

6. Gaylord, B., Gaines, S. D., Siegel, D. A. \& Carr, M. H. Ecol. Appl. 15, 2180-2191 (2005). 